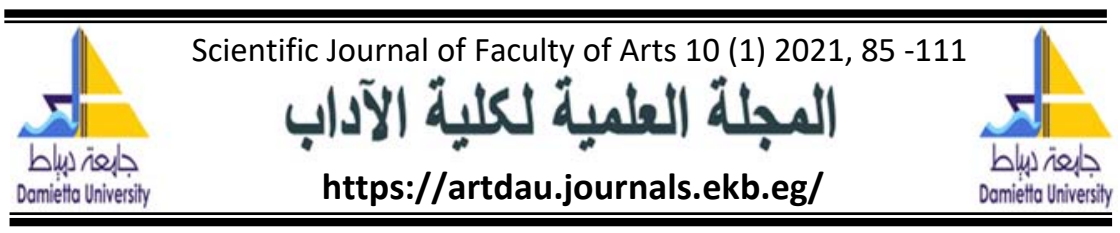

\title{
Tension between Meter and Syntax in Hamlet
}

\section{Ahmad Ismail Qutb Mohammed}

PhD student, English Depart., Faculty of Arts, Port Said University

Abstract

This paper discusses the tension between meter and syntax in Shakespeare's Hamlet. It provides an exemplified survey of the relationship between syntax and meter within and across each line of the selected quotes from the play. It addresses issues that are effectively involved in Shakespeare's use of poetic license and its relation to syntax to enforce his meanings and messages and to portray his characters. It tries to answer these questions: Is the tension between meter and syntax within the line and across a group of lines the same. How do the metrical tools used affect the meaning? To what extent is there a relationship between structure and meaning on the one hand and meter and meaning on the other? The study comes to a conclusion that shows the importance of using meter in giving a certain meaning through the different types of poetic license in Hamlet. It also summaries how the tools and devices used by Shakespeare are quite suitable for serving his intended meanings. To achieve this, the stylistic/analytic approach has been applied.

Keywords:

Shakespeare's Hamlet - meter - syntax - poetic license

Article history:

Received 20 January 2021

Received in revised form 9 February 2021

Accepted 3 March 2021 


\section{Introduction}

Poetic license is known as artistic license, which means to be permitted in a line or group of lines of poetry. Shakespeare uses this many times to convey certain meanings in his plays. It is the writer's freedom to achieve the desired effect behind his use of conventions, facts and the language. Moreover, he may use it to exaggerate certain things, facts or meanings. It also gives the reader some revelations about what is happening between the lines and which do not appear to all people. For example, when Shakespeare changes some regular structures of his lines, he intends certain meanings. Sometimes, he uses comedies in his tragedies; other times, he uses tragic scenes in his comedies. He uses the device of enjambment, where a sentence or a clause runs into the next line, to convey an important message about the speaker's inner feelings.

Usually, there should be ten syllables in iambic pentameter lines. But as a result of the tensions within lines, there may be elision, caesura and enjambment. Sometimes, there is a headless line with nine syllables. Otherwise, there may be lines containing eleven syllables with an extra - usually unstressed - syllable at the end or in the middle of the line. In relation to syntax, the majority of iambic pentameter lines are parallel to syntax which means that the line ends with a meaningful structure. In this case, there is an agreement between meter and syntax. On the other hand, there may be an end-stopped line if syntax and rhythm disagree, or if there is a tension between meter and syntax. These two main kinds of endstopped and run-on lines will be under scrutiny in this study.

The following passages contain lines that mostly give meaningful sentences which are declarative statements, imperatives or interrogatives. It is supposed that each sentence ends at the end of the line. The passages have been chosen from different acts of the play. They are mainly related to the main character, Hamlet in various situations while he has different feelings.

\section{Passage 1: (Act 1, Scene 2, Lines 79 - 89)}

The following passage, taken from Hamlet, shows the conflict or the cases of disagreement between meter and syntax within the line:

\subsection{The source text}

"Seems" madam? Nay, it is. I know not "seems."

'Tis not alone my inky cloak, good mother, Nor customary suits of solemn black, Nor windy suspiration of forced breath 
No, nor the fruitful river in the eye, Nor the dejected havior of the visage, Together with all forms, moods, shapes of grief, That can denote me truly. These indeed "seem," For they are actions that a man might play; But I have that within which passes show, These but the trappings and the suits of woe.

\subsection{Scansion of the passage: (Act 1, Scene 2, Lines 79 - 89)}

\begin{tabular}{|c|c|c|c|c|c|c|c|c|c|c|}
\hline \multicolumn{11}{|c|}{ Table 1 scansion } \\
\hline & \multicolumn{2}{|c|}{ Foot 1} & \multicolumn{2}{|c|}{ Foot 2} & \multicolumn{2}{|c|}{ Foot 3} & \multicolumn{2}{|c|}{ Foot 4} & \multicolumn{2}{|c|}{ Foot 5} \\
\hline \multirow{2}{*}{1} & Seems & $\mathrm{ma}$ & dam $\|$ & nay & it & is $\|$ & I & know & not & seems \\
\hline & - & - & $\mathrm{X}$ & - & $\mathrm{X}$ & - & $\mathrm{X}$ & - & $\mathrm{X}$ & - \\
\hline \multirow{2}{*}{2} & Tis & not a & lone & my & in & ky & cloak\| & good & mo & ther \\
\hline & - & $\mathrm{XX}$ & - & $\mathrm{X}$ & - & $\mathrm{X}$ & - & - & - & $\mathrm{X}$ \\
\hline \multirow{2}{*}{3} & Nor & cust & o & ma & ry & suits & of & so & lemn & black \\
\hline & $\mathrm{X}$ & - & $\mathrm{X}$ & - & $\mathrm{X}$ & - & $\mathrm{X}$ & - & $\mathrm{X}$ & - \\
\hline \multirow{2}{*}{4} & Nor & wind & $\mathrm{y}$ & sus & pi & $\mathrm{ra}$ & tion & of & forced & breath \\
\hline & $\mathrm{X}$ & - & $\mathrm{X}$ & - & $\mathrm{X}$ & - & $\mathrm{X}$ & $\mathrm{X}$ & - & - \\
\hline \multirow{2}{*}{5} & No $\|$ & nor & the & fruit & ful & $\mathrm{ri}$ & ver & in & the & eye \\
\hline & $\mathrm{X}$ & $-\uparrow$ & $\mathrm{X}$ & - & $\mathrm{X}$ & - & $\mathrm{X}$ & - & $\mathrm{x}$ & - \\
\hline \multirow[b]{2}{*}{6} & Nor & the de & jec & ted & ha & vior & of & the & vis & age \\
\hline & $-\uparrow$ & $X X$ & - & $\mathrm{X}$ & - & $\mathrm{X}$ & $\mathrm{X}$ & $-\uparrow$ & - & $\mathrm{X}$ \\
\hline \multirow{2}{*}{7} & To & geth & er & with & all & forms & moods & shapes & of & grief \\
\hline & $\mathrm{X}$ & - & $X$ & $-\uparrow$ & $X$ & - & - & - & $\mathrm{X}$ & - \\
\hline \multirow{2}{*}{8} & That & can de & note & me & tru & ly \| & these & in & deed & seem \\
\hline & - & X X & - & $\mathrm{X}$ & - & $\mathrm{X}$ & $\mathrm{X}$ & $\mathrm{X}$ & - & - \\
\hline \multirow{2}{*}{9} & For & they & are & $\mathrm{ac}$ & tions & that & $\mathrm{a}$ & $\operatorname{man}$ & might & play \\
\hline & $\mathrm{X}$ & $-\uparrow$ & $\mathrm{X} \downarrow$ & - & $\mathrm{X}$ & $-\uparrow$ & $\mathrm{X}$ & - & $\mathrm{X}$ & - \\
\hline \multirow{2}{*}{10} & But & I & have & that & with & in & which & pas & seth & show \\
\hline & $\mathrm{X}$ & $-\uparrow$ & $\mathrm{X} \downarrow$ & $-\uparrow$ & $\mathrm{X}$ & - & $\mathrm{X}$ & - & $\mathrm{X}$ & - \\
\hline \multirow{2}{*}{11} & These & but & the & trap & pings & and & the & suits & of & woe \\
\hline & X & $-\uparrow$ & $X$ & - & X & $-\uparrow$ & $X$ & - & $\mathrm{X}$ & - \\
\hline Agree & \multicolumn{2}{|c|}{4} & \multicolumn{2}{|c|}{5} & \multicolumn{2}{|c|}{6} & \multicolumn{2}{|c|}{4} & \multicolumn{2}{|c|}{7} \\
\hline Disagree & \multicolumn{2}{|c|}{7} & \multicolumn{2}{|c|}{6} & \multicolumn{2}{|c|}{5} & \multicolumn{2}{|c|}{7} & \multicolumn{2}{|c|}{4} \\
\hline
\end{tabular}


Table 2 poetic license used

\begin{tabular}{|c|c|c|c|c|c|c|c|c|c|c|c|}
\hline No & Line & Trochaic & Anapest & Pyrrhic & Promotion & $\begin{array}{c}\text { Demo } \\
\text { tion }\end{array}$ & $\begin{array}{l}\text { Compr } \\
\text { ession }\end{array}$ & Spondaic & $\begin{array}{l}\text { Fem } \\
\text {.end }\end{array}$ & Total & $\%$ \\
\hline 1 & $\begin{array}{l}\text { "Seems," madam? Nay, it } \\
\text { is. I know not "seems." }\end{array}$ & & & & & & & 1 & & 1 & $2 \%$ \\
\hline 2 & $\begin{array}{l}\text { 'Tis not alone my inky } \\
\text { cloak, good mother, }\end{array}$ & 3 & 1 & & & & & 1 & & 5 & $9 \%$ \\
\hline 3 & $\begin{array}{l}\text { Nor customary suits of } \\
\text { solemn black, }\end{array}$ & & & & & & & & & - & - \\
\hline 4 & $\begin{array}{l}\text { Nor windy suspiration of } \\
\text { forced breath, }\end{array}$ & & & 1 & & & & 1 & & 2 & $4 \%$ \\
\hline 5 & $\begin{array}{l}\text { No, nor the fruitful river in } \\
\text { the eye, }\end{array}$ & & & & 1 & & & & & 1 & $2 \%$ \\
\hline 6 & $\begin{array}{l}\text { Nor the dejected havior of } \\
\text { the visage, }\end{array}$ & 3 & 1 & & 2 & & & & & 6 & $11 \%$ \\
\hline 7 & $\begin{array}{l}\text { Together with all forms, } \\
\text { moods, shapes of grief, }\end{array}$ & & & & 1 & & & 1 & & 2 & $4 \%$ \\
\hline 9 & $\begin{array}{l}\text { For they are actions that a } \\
\text { man might play; }\end{array}$ & & & & 2 & 1 & & & & 3 & $5 \%$ \\
\hline 10 & $\begin{array}{l}\text { But I have that within } \\
\text { which passes show, }\end{array}$ & & & & 2 & 1 & & & & 3 & $5 \%$ \\
\hline \multirow[t]{3}{*}{11} & $\begin{array}{l}\text { These but the trappings and } \\
\text { the suits of woe. }\end{array}$ & & & & 2 & & & & & 2 & $4 \%$ \\
\hline & Total & 8 & 3 & 2 & 10 & 2 & - & 5 & - & 30 & $55 \%$ \\
\hline & Disagre. per passage & $15 \%$ & $5 \%$ & $4 \%$ & $18 \%$ & $4 \%$ & - & $9 \%$ & - & $55 \%$ & 55 \\
\hline
\end{tabular}




\subsection{Statistical Analysis of the Passage:}

The statistics show that there is a big amount of disagreement between foot and word boundaries in most of the feet in the passage. Although the agreement amount is more than the disagreement, there is much more tension between meter and syntax in many lines of this part of the play. The following chart shows this statistical analysis of the tension within the line:

Table 3 meter-syntax tension

\begin{tabular}{|c|c|c|c|c|c|c|c|}
\hline Foot & One & Two & Three & Four & Five & Total & Percent \\
\hline Agree & 5 & 4 & 6 & 6 & 8 & 29 & $53 \%$ \\
\hline Disagree & 6 & 7 & 5 & 5 & 3 & 26 & $47 \%$ \\
\hline
\end{tabular}

The following two charts show these cases of tension in the passage; the first chart shows the relation between meter and syntax, and the second chart shows the poetic license used in the passage.

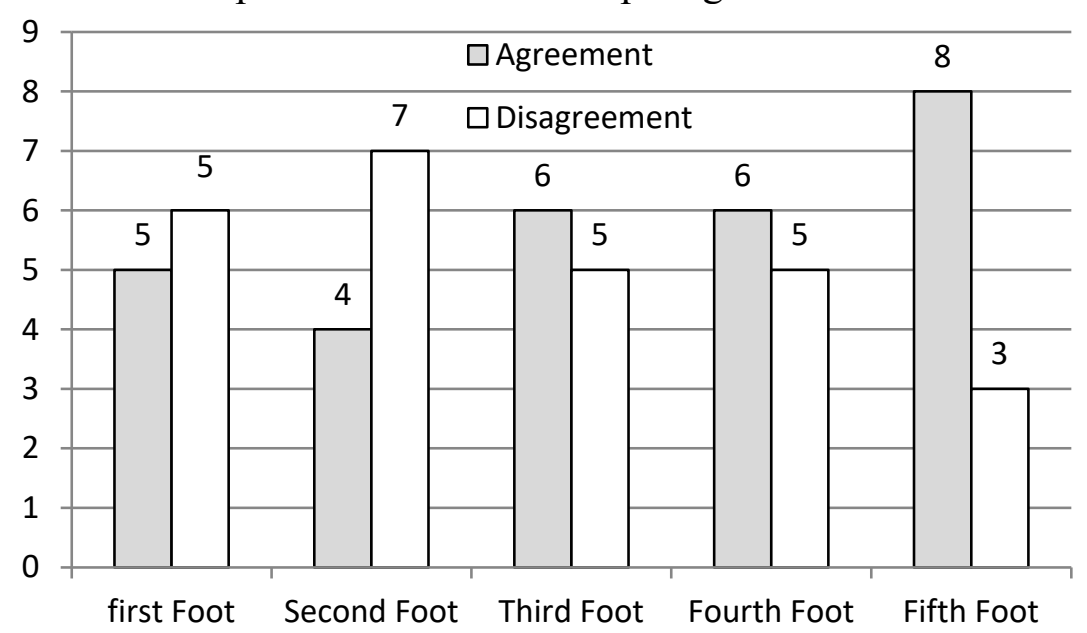

Fig. 1 meter-syntax

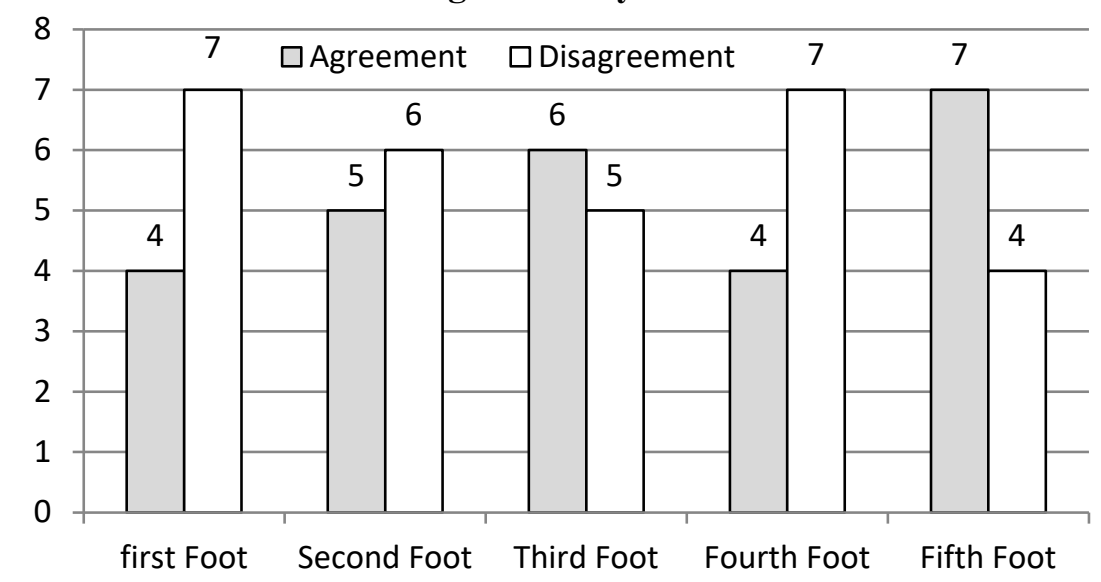

Fig. 2 poetic license 
In the above passage, Hamlet is expressing his anger and objecting to what his mother did and to her accusing him of showing unusual sorrow after the death of his father. He resents his mother's marriage to his uncle.

Swazo (2008) maintains that:

The effect of the remarriage of a parent on the mind of his/her child is devastating and the child needs to be treated with extra care and attention and not to be neglected at all. It is difficult for a variety of reasons for the child to accept the second marriage of his parent (418).

Hamlet appears to be very upset. The tone rises in the first line through the repetition of certain words. He accuses his mother of false grief for her ex-husband. He wants to say that she is looking sad but it is fake. Hamlet is physically demonstrating his suffering. By his visible appearance in the black cloak, he wants to assure the fact that this is what he actually has inside and what they should have towards this sad situation of the loss of his father as well. The scene reflects Shakespeare's skill of using less images and metaphors to portray several meanings and feelings. This skill is clear in Hamlet's dark clothes, his crying and grief. Hamlet says that all this outside appearence is nothing if it is compared with what is actually going inside him and what he really feels.

Here, Hamlet is focusing on the disparity between appearance and reality. Sjolin (2017) assumes that "Gertrude is a 'bad' or at least a 'thoughtless' mother, since she shows no understanding for her son's grieving for his father, especially in her line 'Why seems it so particular with thee?" (298).

Although Hamlet tries to be wise and calm, his words do not show that. Swazo (2018) remarks that "Hamlet should strike a proper balance between thought and action" (418). Swazo adds that "if thought is not given the practical shape of action, it is an exercise in futility. But in Shakespeare's days it was a fashion to appear melancholy in order to be considered wise" (418). Hamlet's speech is a reaction to his mother's question "Why seems it so particular with thee?" His use of the anaphora "nor" expresses his own grief and contrasts his mother's artificial one. His words show his mother's lack of grief and assure her untrue feelings. This appears clearly in the seventh line with words such as "all forms, moods, shapes of grief." The black color of Hamlet's suit is quite suitable for his sadness. On the other hand, the colorful clothes of both Claudius and Gertrude show the opposite.

To achieve his goals, Hamlet tries to use irony in different situations. In the above passage, he shows his hatred of deception through the device of irony. Johnston (2007) observes that "Hamlet is a revenge play" (1). 
Hamlet insists that his mother's appearance is completely different from her reality. He implies certain meanings by the use of his words and meter. He objects to her word "seem" saying that he only mourns truthfully and that his sorrow is real. It is clear in Hamlet's speech that he has something inside which reflects his objection to the fast marriage between Claudius and Gertrude. He regards that marriage to be illegal since Gertrude is a sister in law to Claudius. Another main reason is that Claudius has swept away the throne, even though Hamlet not Claudius should have been named the new king after the death of his father. As a result for what has happened, Hamlet believes that everybody else, excepthimself, disrespects his father's memory. Basically, Hamlet does not accept Claudius stepping up and taking over as the king. The craftsmanship of Shakespeare arises in his presenting of Claudius as a smart person who has control over all other characters in the play, except Hamlet who is the only person rejecting what is happening in Denmark. Hamlet believes that Claudius breaks at least two important political issues of the state which are his marriage to his sister in law and his taking of the throne while young Hamlet is alive. Akram and Qasim (2016) assume that "Hamlet is at a confusing edge of acceptance and non-acceptance of the reality. Indirectly, Hamlet uses irony and criticizes his mother for not mourning the death of her husband" (74).

As for the structure of the whole extract, it is clear that Shakespeare has used only two main sentences; the first line forms sentence number one and then from line two to the end of the next eight lines occurs the second sentence. He uses so many words and adjectives to add more complexity and expressions to his work. For example, the expression "the fruitful river in the eye" can be formed by another writer with "constant crying", but Shakespeare's language gives much more complication and strong imageries. Moreover, this use of structures and images makes the style of writing more enjoyable and unique. Actually, he gives his audience or readers much more meanings within or beyond the lines themselves than just the basic meanings of these lines.

One more important point which is clear in this quotation and many other quotations in the play is the portrayal of women. In Hamlet, the portrayal of women is closely related to authority, sexuality and obedience. Sjolin (2017) assumes that "Gertrude and Ophelia are two of the most difficult female Shakespearean roles: they are 'strange', 'under-written' and 'apparently inconsistent'" (295). Ophelia's role as a character seems to be weak and submissive based on the fact that she takes commands from both her father and brother, and sometimes Hamlet while her brother Laertes is shown to be introduced as pretty commanding her, and it seems 
that he sees himself as superior to his sister Ophelia, based on the tone used in the lines that he utters in front of her.

The other main female character, Gertrude, is portrayed to obey Claudius or Hamlet when they ask her to do something. Jajja (2014) remarks that "Gertrude, the wife of Hamlet the King, is portrayed as a negative stereotype of a woman" (231). She seems to be dependent. She does only what men ask her to do. Jajja adds that:

such women are associated with darkness and sexuality.

They are whores and bitches. She re-marries Claudius, the bother of King Hamlet, within days of the death of her husband. It is her conduct that has pushed the Prince Hamlet to the thought of committing suicide"(231).

Throughout the play, it is clear that Gertrude is extremely shown as a dependent woman because of her poor decisions and her dependence on Claudius to kill her previous husband. Her question to Hamlet why he feels such a seemingly strong grief-stricken for his father makes Hamlet so furious, which is perceived in his bitter reply to her. In Hamlet, Shakespeare uses the two main women characters: Ophelia and Gertrude to showcase what women were like during his time. Unlike Ophelia and Gertrude, Claudius has power and uses it over Gertrude. Although Hamlet also has power, he does not use it over both his mother, Gertrude and his beloved, Ophelia. For instance, Hamlet orders Ophelia saying "Get thee to a nunnery". Moreover, he tells his mother Gertrude "Frailty, thy name is a woman". Gertrude is the main reason in making Hamlet think of her sexuality through her quick marriage to Claudius shortly after her husband's death. This negative behavior pushes Hamlet to think badly about his mother since this makes him both over sad towards his father's death and his deprivation of the throne.

Meter and structures show this clearly. Hamlet's harsh addressing of his mother as a "madam" reflects his frustration and anger. This word indicates that Hamlet wants to insult his mother for her speedly remarriage. This gives the reader the feeling that the relationship between Hamlet and his mother is complicated. He sometimes dares to call her "madam" and at other times "woman". Sjolin (2017) elaborates this point:

The mere fact that the words have been changed (and that the iambic pentameter is momentarily abandoned) may make an audience listen more attentively, but the focus is also moved from stressing that all the problems mentioned are experienced by men to talking about more typically female afflictions (309).

Gertrude's passivity allows Claudius to kill Hamlet's father, marry his mother and become the king. Gertrude just connects Hamlet, the son, to 
her new husband. For Hamlet, she is his mother, and for Claudius, she is his wife. Keys (2012) clarifies that "there is a deep connection between an apprehension of human finitude and the authenticity of a life" (17). This connection raises the conflict between Hamlet and his uncle. Jajja (2014) observes that "Gertrude's right to re-marry is not accepted. Prince Hamlet calls his mother the most pernicious woman, a damned smiling villain"(231). Moreover, the relationship between Gertrude and Claudius hurts Hamlet's feelings. He seems to be unable to think properly or to make a decision. Jajja (2014) adds that "Hamlet's reaction to the marriage of his mother is only reflective of the operation of patriarchy" (236). Hamlet sees his mother's quick second marriage as a weakness in her character. He considers this remarriage as a sign of a weak woman who cannot stand to be alone.

\subsection{Syntactic Analysis of the Passage}

In the first line of the above passage, Hamlet uses two full stops and a question mark. He starts his speech with an interrogation, rejecting his mother's description of him as seemingly sad. The sentence structure in the first line gives certain meanings: first of all, through putting the verb "seem" before the vocative "madam" and deleting the subject which is supposed to be the pronoun "I", the structure of the interrogation gives the meaning that Hamlet is furiously rejecting his mother's description of him as seeming sad. Presenting the verb "seem" at the beginning of the sentence clarifies Hamlet's inner feeling of sorrow. He wants to compare his inside feelings to those of his mother who should feel guilty. "Seems madam?" is a rhetorical question; he does not seek for an answer; he denies her false feelings towards his late father who was her ex-husband. It is better for a person to make the right decision in the appropriate time. Sharma (2014) accentuates that "Hamlet, in spite of being a very wise and learned man, has forgotten the wise saying: 'Never put off till tomorrow what you can do today" (419).

The use of different forms of negation, such as "nay", "not" and "nor", is repeated in the first six lines of the passage which reflects the severe rejection from Hamlet to what happens after his father's death.

\subsection{Lexical Statistics}

By looking at the parts of speech used in the passage, it is noticed that:

Table 4 (major word classes)

\begin{tabular}{|r|c|c|c|c|}
\hline Part of speech & Nouns & Adjectives & Verbs & Adverbs \\
\hline Total number & 21 & 9 & 11 & 6 \\
\hline Percentage & $45 \%$ & $19 \%$ & $23 \%$ & $13 \%$ \\
\hline
\end{tabular}

Considering the above table and the source passage, it is clear that lines $3,4,5,6,7$, besides the last one do not contain verbs, do not refer to any action or movement. On the contrary, they are just descriptions of feelings. 
This reflects Hamlet's status of jumbled thinking and state of mind. In these lines, he denies their misunderstanding of his grief relating it just to his physical appearance. He wants to say that his feeling of sorrow for losing his father is true and not faked or fabricated. Grammatically, all these verbless lines are called fragments since they do not give complete sentences; they just add more information to the main sentences.

\section{Passage Two from Hamlet (Act 2, Scene 2, Lines 598-607)}

\subsection{The source text:}

A damned defeat was made. Am I a coward?

Who calls me "villain"? breaks my pate across?

Plucks off my beard and blows it in my face?

Tweaks me by the nose? gives me the lie i' th' throat

As deep as to the lungs? Who does me this?

Ha! 'Swounds, I should take it! For it cannot be

But I am pigeon-livered and lack gall

To make oppression bitter, or ere this

I should have fatted all the region kites

With this slave's offal. Bloody, bawdy villain! 
Table 5 scansion of the passage

\begin{tabular}{|c|c|c|c|c|c|c|c|c|c|c|c|}
\hline \multirow[b]{2}{*}{1} & \multicolumn{2}{|c|}{ Foot 1} & \multicolumn{2}{|c|}{ Foot 2} & \multicolumn{2}{|c|}{ Foot 3} & \multicolumn{2}{|c|}{ Foot 4} & \multicolumn{2}{|c|}{ Foot 5} & \\
\hline & $\begin{array}{l}\mathrm{A} \\
\mathrm{X} \\
\end{array}$ & $\begin{array}{c}\text { damn'd } \\
-\end{array}$ & $\begin{array}{c}\text { de } \\
\mathrm{X}\end{array}$ & $\begin{array}{c}\text { feat } \\
- \\
\end{array}$ & $\begin{array}{c}\text { was } \\
\mathrm{x} \\
\end{array}$ & $\begin{array}{c}\text { made } \| \\
-\end{array}$ & $\begin{array}{c}\mathrm{Am} \\
\mathrm{x}\end{array}$ & $\begin{array}{c}\mathrm{I} \\
-\uparrow\end{array}$ & $\begin{array}{l}\mathrm{a} \\
\mathrm{x}\end{array}$ & $\begin{array}{c}\text { coward } \\
-\end{array}$ & \\
\hline 2 & $\begin{array}{c}\text { Who } \\
\mathrm{x}\end{array}$ & $\begin{array}{c}\text { calls } \\
-\end{array}$ & $\begin{array}{c}\mathrm{me} \\
\mathrm{x}\end{array}$ & $\begin{array}{l}\text { vil } \\
- \\
\end{array}$ & $\begin{array}{c}\text { lain } \| \\
\mathrm{x}\end{array}$ & $\begin{array}{c}\text { breaks } \\
-\end{array}$ & $\begin{array}{c}\text { my } \\
\mathrm{x}\end{array}$ & $\begin{array}{c}\text { pate } \\
-\end{array}$ & $\begin{array}{l}\mathrm{a} \\
\mathrm{x}\end{array}$ & $\begin{array}{c}\text { cross } \\
-\end{array}$ & \\
\hline 3 & $\begin{array}{c}\text { Plucks } \\
- \\
\end{array}$ & $\begin{array}{c}\text { off } \\
\mathrm{x}\end{array}$ & $\begin{array}{c}\text { my } \\
\mathrm{x}\end{array}$ & $\begin{array}{c}\text { beard } \\
-\end{array}$ & $\begin{array}{c}\text { and } \\
\mathrm{x}\end{array}$ & $\begin{array}{c}\text { blows } \\
-\end{array}$ & $\begin{array}{l}\text { it } \\
\mathrm{x}\end{array}$ & $\begin{array}{c}\text { in } \\
-\uparrow\end{array}$ & $\begin{array}{c}\text { my } \\
x\end{array}$ & $\begin{array}{c}\text { face } \\
-\end{array}$ & \\
\hline 4 & $\begin{array}{c}\text { Tweaks } \\
-\end{array}$ & $\begin{array}{c}\mathrm{me} \\
\mathrm{x}\end{array}$ & $\begin{array}{l}\text { by } \\
\mathrm{x}\end{array}$ & $\begin{array}{c}\text { the } \\
x\end{array}$ & $\begin{array}{c}\text { nose } \| \\
-\end{array}$ & $\begin{array}{c}\text { gives } \\
-\end{array}$ & $\begin{array}{c}\mathrm{me} \\
\mathrm{x}\end{array}$ & $\begin{array}{c}\text { the } \\
x\end{array}$ & $\begin{array}{l}\text { lie } \\
-\end{array}$ & $\begin{array}{l}\text { in the } \\
\mathrm{X} \quad \mathrm{X}\end{array}$ & $\begin{array}{c}\text { throat, } \\
-\end{array}$ \\
\hline 5 & $\begin{array}{c}\text { As } \\
\mathrm{X}\end{array}$ & $\begin{array}{c}\text { deep } \\
-\end{array}$ & $\begin{array}{l}\text { as } \\
\mathrm{x} \\
\end{array}$ & $\begin{array}{c}\text { to } \\
-\uparrow\end{array}$ & $\begin{array}{l}\text { the } \\
\mathrm{x}\end{array}$ & $\begin{array}{c}\text { lungs } \\
- \\
\end{array}$ & $\begin{array}{c}\text { who } \\
\mathrm{X}\end{array}$ & $\begin{array}{c}\text { does } \\
- \\
\end{array}$ & $\begin{array}{c}\mathrm{me} \\
\mathrm{x}\end{array}$ & $\begin{array}{l}\text { this } \\
-\uparrow \\
\end{array}$ & \\
\hline 6 & $\begin{array}{c}\mathrm{Ha} \\
\mathrm{x}\end{array}$ & $\begin{array}{c}\text { swounds } \| \\
-\end{array}$ & $\begin{array}{l}\mathrm{I} \\
\mathrm{X}\end{array}$ & $\begin{array}{c}\text { should } \\
-\uparrow\end{array}$ & $\begin{array}{c}\text { take } \\
-\end{array}$ & ${ }_{\mathrm{x}}^{\text {it }}$ & $\begin{array}{l}\text { for it } \\
\mathrm{X} \quad \mathrm{X}\end{array}$ & $\begin{array}{c}\text { can } \\
-\uparrow\end{array}$ & $\begin{array}{c}\text { not } \\
\mathrm{x}\end{array}$ & $\begin{array}{l}\text { be } \\
-\end{array}$ & \\
\hline 7 & $\begin{array}{c}\text { But } \\
\mathrm{X}\end{array}$ & $\begin{array}{c}\mathrm{I} \\
-\uparrow\end{array}$ & $\begin{array}{c}\mathrm{am} \\
\mathrm{X}\end{array}$ & $\begin{array}{l}\text { pig } \\
-\end{array}$ & $\begin{array}{c}\text { eon- } \\
\mathrm{X}\end{array}$ & $\begin{array}{l}\text { liv } \\
-\end{array}$ & $\begin{array}{c}\text { er'd } \\
x\end{array}$ & $\begin{array}{c}\text { and } \\
\mathrm{x}\end{array}$ & $\begin{array}{c}\text { lack } \\
-\end{array}$ & $\begin{array}{c}\text { gall } \\
-\end{array}$ & \\
\hline 8 & $\begin{array}{l}\text { To } \\
\mathrm{X}\end{array}$ & $\begin{array}{c}\text { make } \\
-\end{array}$ & $\begin{array}{l}0 \\
\mathrm{X}\end{array}$ & $\begin{array}{c}\text { ppres } \\
-\end{array}$ & $\begin{array}{c}\text { sion } \\
\mathrm{x}\end{array}$ & $\begin{array}{l}\text { bit } \\
- \\
\end{array}$ & $\begin{array}{c}\text { ter, } \\
\mathrm{x}\end{array}$ & $\begin{array}{c}\text { or } \\
-\uparrow \\
\end{array}$ & $\begin{array}{c}\text { ere } \\
\mathrm{x}\end{array}$ & $\begin{array}{l}\text { this } \\
-\uparrow\end{array}$ & \\
\hline 9 & $\begin{array}{l}\mathrm{I} \\
\mathrm{X} \\
\end{array}$ & $\begin{array}{c}\text { should } \\
-\uparrow\end{array}$ & $\begin{array}{c}\text { have } \\
\mathrm{x}\end{array}$ & $\begin{array}{l}\text { fat } \\
-\end{array}$ & $\begin{array}{c}\text { ted } \\
\mathrm{X}\end{array}$ & $\begin{array}{l}\text { all } \\
-\end{array}$ & $\begin{array}{c}\text { the } \\
\mathrm{x}\end{array}$ & $\begin{array}{c}\text { reg } \\
-\end{array}$ & $\begin{array}{c}\text { ion } \\
\mathrm{x}\end{array}$ & $\begin{array}{c}\text { kites } \\
-\end{array}$ & \\
\hline 10 & $\begin{array}{c}\text { With } \\
\text { X }\end{array}$ & $\begin{array}{l}\text { This } \\
-\uparrow\end{array}$ & $\begin{array}{c}\text { slave's } \\
-\end{array}$ & $\begin{array}{l}\text { of } \\
\mathrm{x}\end{array}$ & $\begin{array}{c}\text { fal: } \\
x\end{array}$ & $\begin{array}{c}\text { bloo } \\
-\end{array}$ & $\begin{array}{c}\mathrm{dy}, \\
\mathrm{x}\end{array}$ & $\begin{array}{c}\text { baw } \\
-\end{array}$ & $\begin{array}{l}\mathrm{dy} \\
\mathrm{x}\end{array}$ & $\begin{array}{l}\text { vill } \\
-\end{array}$ & $\begin{array}{c}\text { ain! } \\
\mathrm{x}\end{array}$ \\
\hline Agree & & 5 & & & & & & & & 5 & \\
\hline Disagree & & 5 & & & & & & & & 5 & \\
\hline
\end{tabular}


Table 6 poetic license used

\begin{tabular}{|c|c|c|c|c|c|c|c|c|c|c|c|}
\hline No & line & ctrochai & tanapes & cpyrrhi & promotion & demotion & epic & spondaic & fem.end & Total & $\%$ \\
\hline 1 & $\begin{array}{l}\text { A damned defeat was made. Am I a } \\
\text { coward? }\end{array}$ & & & & 1 & & & & & 1 & $4 \%$ \\
\hline 2 & $\begin{array}{l}\text { Who calls me "villain"? breaks my } \\
\text { pate across? }\end{array}$ & & & & & & & & & - & - \\
\hline 3 & $\begin{array}{l}\text { Plucks off my beard and blows it in } \\
\text { my face? }\end{array}$ & 1 & & & 1 & & & & & 2 & $9 \%$ \\
\hline 4 & $\begin{array}{l}\text { Tweaks me by the nose? gives me the } \\
\text { lie i' th' throat }\end{array}$ & 1 & 2 & 1 & & & & 1 & & 5 & $22 \%$ \\
\hline 5 & $\begin{array}{l}\text { As deep as to the lungs? Who does } \\
\text { me this? }\end{array}$ & & & & 2 & & & & & 2 & $9 \%$ \\
\hline 6 & $\begin{array}{l}\text { Ha! 'Swounds, I should take it! For it } \\
\text { cannot be }\end{array}$ & 1 & & & 2 & & 1 & & & 4 & $17 \%$ \\
\hline 7 & But I am pigeon-livered and lack gall & & & 1 & 1 & & & 1 & & 3 & $13 \%$ \\
\hline 8 & To make oppression bitter, or ere this & & & & 2 & & & & & 2 & $9 \%$ \\
\hline 9 & $\begin{array}{l}\text { I should have fatted all the region } \\
\text { kites }\end{array}$ & & & & 1 & & & & & 1 & $4 \%$ \\
\hline 10 & $\begin{array}{l}\text { With this slave's offal. Bloody, bawdy } \\
\text { villain! }\end{array}$ & 1 & & & 1 & & & & & 3 & $13 \%$ \\
\hline & Total & 4 & 2 & 2 & 11 & - & 1 & 2 & & 23 & $46 \%$ \\
\hline & Disagreement per passage & $17 \%$ & $9 \%$ & $9 \%$ & $48 \%$ & - & $4 \%$ & $9 \%$ & & $46 \%$ & 50 \\
\hline
\end{tabular}




\subsection{Statistical Analysis of the Passage:}

The statistics show the opposite of the previous passage. Here, the amount of disagreement between foot and word boundaries in most of the feet is less than that of agreement. This reflects less conflict and tension between meter and syntax in this part of the play. The following chart shows this statistical analysis of the tension within the line:

Table 7 meter-syntax tension

\begin{tabular}{|c|c|c|c|c|c|c|c|}
\hline Foot & One & Two & Three & Four & Five & Total & \% \\
\hline Agree & 10 & 5 & 5 & 6 & 8 & $\mathbf{3 4}$ & $\mathbf{6 8 \%}$ \\
\hline Disagree & - & 5 & 5 & 4 & 2 & $\mathbf{1 6}$ & $\mathbf{3 2 \%}$ \\
\hline
\end{tabular}

Here are two charts that show these cases of tension in the passage; the first one shows the relation between meter and syntax, and the second shows the poetic license used in the passage.

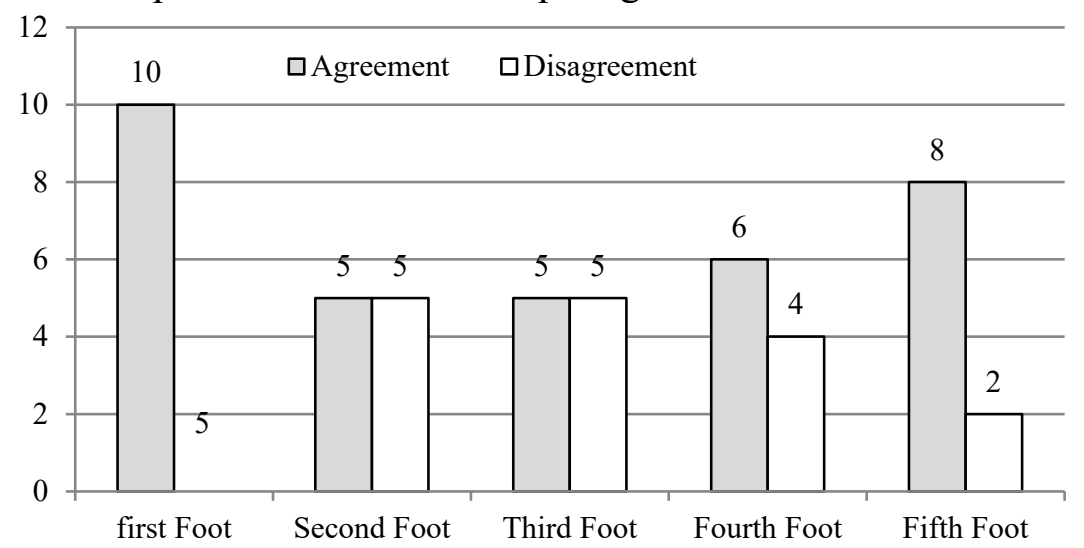

Fig 3 meter-syntax

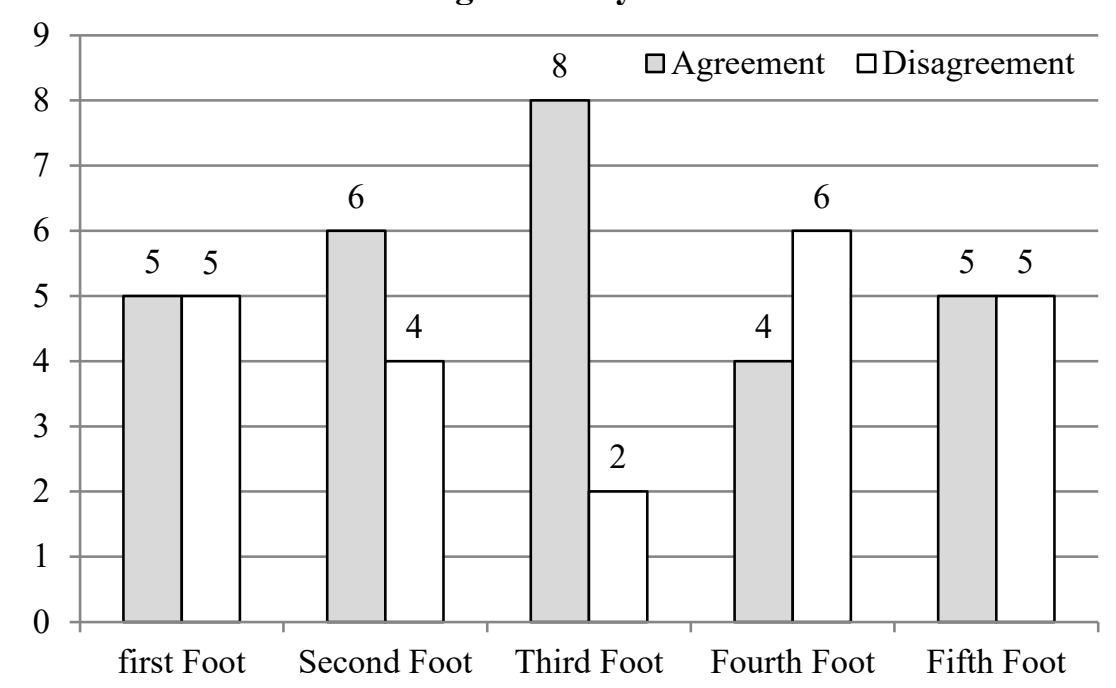

Fig. 4 poetic license 
Here, Hamlet expresses his fear about making a decision about killing his uncle. It is quite similar to oedipal complex which refers to the killing of the father and marrying the mother. So, Hamlet feels unconscious and unable to accept what happens around him or even to take revenge to the death of his father. Sharma (2014) elucidates that "Hamlet is the story of an over-thinking philosopher, that is, Prince Hamlet" (417). Hamlet's words show that he himself is unable to take an action against his uncle though he is aware of what happens after the ghost of his father has told him the true story. He expresses anger for not having done anything until this point of the play. Hamlet compares himself to one of the actors who visited him and who were able to express their feelings to take action and managed to cause the audience to feel what they feel even though they have no real reasons to do so. In contrast, Hamlet finds that he is unable to do the same as the actor does even though he has all reasons to do so. This contrast makes Hamlet believe he is a coward. The big number of rhetorical questions such as "Am I a coward?", "who calls me villain?", "breaks my pate across?" and "tweaks me by the nose?" that he asks himself clarifies this point. Moreover, he compares his less courage to a harmless "pigeon".

Akram and Qasim (2016) assume that "the play depicts the disparity of man and his actions. This makes Hamlet a mystery" (73). The word 'villain' describes Hamlet's inner evil feeling. It also means that he denies any body thinking of him as an evil character. Again, he is using irony in his speech. He thinks of himself as a coward using words such as "most brave" in a satirical and ironic way. Consequently, this soliloquy clearly declares Hamlet's self-knowledge and self-loathing. Metaphorically, he compares himself to an "ass" and to a "fool". He uses irony to tell the audience about the fact that he only verbally acts expressing feelings and emotions and never deeds. Seely (2012) maintains that Shakespeare uses these soliloquies to show Hamlet suffering, asserting that "Hamlet begins as emotionally wounded, and concludes as resigned and determined" (1).

The iambic pentameter gives Hamlet a chance to speak freely. He seems a well-educated prince. He thinks a lot of people's words and actions but at the same time he is unable to control his feelings and emotions. He sees himself better than the actor he brought to act the play about the death of his father. Keys (2012) remarks that "Hamlet is constantly aware of his capacity to reconfigure his sense of self" (139). Akram and Qasim (2016) maintain that "the evidence of the text and what it implies when it is put into an action of performance cannot be confirmed. The words have lost and changed meanings and gained new ones" (73). 
On the other hand, Hamlet sees himself a coward since he is unable to kill Claudius up to this moment of the play. Bernáth (2013) states that:

Hamlet is not just about revenge and its delay, not even only about death or the afterlife, with its various implications, including the moral or the religious ones. However, death is certainly a central, overriding theme, and it tends to appear together with its philosophical and religious connotations (36-37).

Hamlet thinks if he was brave enough, he would have already killed his uncle, but this has not happened till now. Keys (2012) maintains that:

Hamlet experiences himself as an individual whose sense of self is shaped by his immediate apprehensions of the world. But he also recognizes that his consciousness imparts meaning to the world, and this is what allows him to have a degree of power over his own subjectivity" (107). This monologue said by Hamlet attracts the reader to understand the character well. Sjölin (2017) maintains that "Hamlet's soliloquies are to a large extent about the human condition and therefore applicable to any human being, regardless of gender; but in his dialogues Hamlet frequently shows himself to be a misogynist" (333). In his soliloquies, Hamlet usually talks about different characters including himself. Johnston (2001) states that:

Hamlet's soliloquies are marked by sudden changes of subject, self-urging to put something out of his mind accompanied by an inability to do so, attacks on himself for all his verbalizing, and a sense of despair that all this talk is getting him no closer to any sort of answer which will clarify the world sufficiently to enable him to act (6).

\subsection{Syntactic Analysis of the Passage}

The word "kite" is symbolic. It is used to refer to birds that eat insects and other small creatures. It has a great relation to the word "offal" which means the remains of eaten animals. Johnston (2001) states that "Hamlet's vocabulary, which characteristically features short colloquial words evocative of a mood of exhaustion, contempt, disgust--a range of feelings of extreme unpleasantness: "fardels," "grunt," "sweat," "nasty sty," "vicious mole," "rank and gross," "slave's offal," and so on" (6). Hamlet wants to say that his uncle is a villain causing him a great pain. Johnston (2001) maintains that: 
In public, Claudius is smooth, polished, confident; in private or with Gertrude he is a troubled spirit; in public Polonius is frequently something of a verbal buffoon; in private he is matter of fact and shrewd. Hamlet plays all sorts of roles, shifting gears from one scene to the next, using language as a survival tool to keep the people he interacts with off guard, puzzled, on the defensive (10).

The end-stopped lines in this passage are used to show Hamlet's calmness though the other characters in the play scorn him and see him as "villain". They do "lie" as deep as to the lungs. Hadfield (2014) states that "Hamlet represents the consequences of an undesirable succession and shows the disastrous events precipitated by the advent of the new reign" (577). Hamlet feels very angry at being nothing while he should kill his uncle and become the king. His words give the impression of his inner emotional conflict. He feels lonely after losing his beloved father and after the fast marriage of his mother to his uncle who is accused of killing his noble father. This feeling of loneliness causes him to ponder over the matter. This emotion suits his use of end-stopped lines. Bloom (2009) states that "Hamlet's suffering is because there is a substantial gap between knowing and action, and between the mind and the body. The intellectual world is impotent in the reality of flesh" (74). Also, Seely (2012) assumes that "Hamlet schemes to exact revenge; both use murder as the means to their end" (1). Commenting on the language used by Shakespeare in Hamlet, Seely declares that Shakespeare uses soliloquies to reflect Hamlet's suffering, asserting that "Hamlet begins as emotionally wounded, and concludes as resigned and determined" (1). They display Hamlet's distress and emotional fragility. The lines are full of caesura or pauses especially in the middle of the lines:

Who calls me villain? || breaks my pate a cross?

So, this soliloquy is important for many reasons. Firstly, Hamlet swears to revenge his father's death but till now at this point of the play he does nothing. Secondly, he expresses anger of himself for the previous reason which is not having done anything yet. He compares himself to one of the visiting actors, causing the audience to feel what he feels. Thirdly, the number of rhetorical questions he asks himself and regarding himself as a coward are very significant in passing the message away for both himself and the audience as well. He portrays himself lacking courage as a harmless pigeon, which is a great metaphor.

Another important thing about this soliloquy is that Hamlet displays himself as having self-knowledge and self-loathing. He compares himself to an ass and describes himself as a fool person. He uses sarcasm by mentioning that it is indeed praise of him when driven by heaven and 
hell to commit his vengeance. He uses similes and metaphors like comparing himself to a whore, an ass and a pigeon. Moreover, in his monologue, Hamlet shows disdain to his uncle Claudius saying.

I should have fatted all the region kites

With this slave's offal. Bloody, bawdy villain!

He uses several metaphors and adjectives to express his intense pain. Finally, this monologue reveals that Hamlet does not entirely trust the ghost declaring that the spirit he has seen may be the devil, and the devil has power to portray different shapes. Hamlet also declares that he needs better background than this which may be abused by the devil.

\subsection{Lexical Statistics:} noticed that:

When looking at the parts of speech used in the passage, it is Table 8 major word classes

\begin{tabular}{|r|c|c|c|c|}
\hline Part of speech & Nouns & Adjectives & Verbs & Adverbs \\
\hline Total number & 18 & 5 & 16 & 2 \\
\hline Percentage & $44 \%$ & $12 \%$ & $39 \%$ & $5 \%$ \\
\hline
\end{tabular}

Having a look at both the above table and the source passage, it is clear that the biggest number of parts of speech used in this passage is nouns and verbs. More use of verbs means much more meaning even if they are helping or linking verbs not action verbs since they connect the subject of the sentence to its other extra relevant information. So, this big number of verbs and nouns in the passage explains the intensity of feeling that Hamlet has especially when he is alone.

Most of the verbs used in the passage are action verbs which help in moving the action of the play and show more inner conflict inside Hamlet's thinking. As verbs play an important role in the text, their tense plays a vital role too. Here, most of the verbs used by Hamlet are at present, which indicates that the action is actually being carried at the moment. They are quite suitable to the case of a soliloquy. Nearly, all lines have sentences.

\section{Passage Three from Hamlet (Act 1, Scene 2, Lines 133-339)}

\subsection{The Source Text:}

$O$, that this too, too sullied flesh would melt,

Thaw, and resolve itself into a dew,

Or that the Everlasting had not fixed

His canon 'gainst self-slaughter! O God, God,

How weary, stale, flat, and unprofitable

Seem to me all the uses of this world! 
Table 9 scansion

\begin{tabular}{|c|c|c|c|c|c|c|c|c|c|c|c|}
\hline \multirow{3}{*}{1} & \multicolumn{2}{|c|}{ Foot 1} & \multicolumn{2}{|c|}{ Foot 2} & \multicolumn{2}{|c|}{ Foot 3} & \multicolumn{2}{|c|}{ Foot 4} & \multicolumn{2}{|c|}{ Foot 5} & \\
\hline & Oh $\|$ & that & this & too $\|$ & too & sol & id & flesh & would & melt & \\
\hline & $X$ & $-\uparrow$ & $\mathrm{x}$ & $-\uparrow$ & $\mathrm{x}$ & - & $\mathrm{x}$ & - & $\mathrm{x}$ & - & \\
\hline \multirow[t]{2}{*}{2} & Thaw\| & and & re & solve & it & self & in & to & $\mathrm{a}$ & dew & \\
\hline & - & $\mathrm{x}$ & $\mathrm{x}$ & - & $\mathrm{x}$ & - & $\mathrm{x}$ & $-\uparrow$ & $\mathrm{x}$ & - & \\
\hline \multirow[t]{2}{*}{3} & Or & that & the & $\mathrm{Ev}$ & er & last & ing & had & not & fix'd & \\
\hline & $\mathrm{X}$ & $-\uparrow$ & $\mathrm{x}$ & - & $\mathrm{x}$ & - & $\mathrm{x}$ & - & $\mathrm{x}$ & - & \\
\hline \multirow[t]{2}{*}{4} & His & can & on & 'gainst & self- & slaugh & (ter) $\| \mathrm{O}$ & God\| & $\mathrm{O}$ & God & \\
\hline & $\mathrm{X}$ & - & $\mathrm{x}$ & - & - & - & (x) $\mathrm{x}$ & - & $\mathrm{x}$ & - & \\
\hline \multirow[t]{2}{*}{5} & How & wear & $\mathrm{y}$ & stale & flat & and & un & prof & $\mathrm{i}$ & ta & ble \\
\hline & X & - & $\mathrm{x}$ & - & $X \downarrow$ & $-\uparrow$ & $\mathrm{x}$ & - & $\mathrm{x}$ & - & $\mathrm{x}$ \\
\hline \multirow[t]{2}{*}{6} & Seem & to & me & all & the & us & es & of & this & world & \\
\hline & - & $\mathrm{x}$ & $\mathrm{x}$ & - & $\mathrm{x}$ & - & $\mathrm{x}$ & $-\uparrow$ & $\mathrm{x}$ & - & \\
\hline Agree & \multicolumn{2}{|c|}{2} & \multicolumn{2}{|c|}{5} & \multicolumn{2}{|c|}{5} & \multicolumn{2}{|c|}{4} & \multicolumn{2}{|c|}{6} & \\
\hline Disagree & \multicolumn{2}{|c|}{4} & \multicolumn{2}{|c|}{1} & \multicolumn{2}{|c|}{1} & \multicolumn{2}{|c|}{2} & \multicolumn{2}{|c|}{ 0 } & \\
\hline
\end{tabular}


Table 10 poetic license used

\begin{tabular}{|c|c|c|c|c|c|c|c|c|c|c|c|}
\hline No & Line & Trochaic & Anapest & P yrrhic & Promotion & Demotion & Epic & Spondaic & Fem.end & Total & $\%$ \\
\hline 1 & $\begin{array}{l}\text { O, that this too, too } \\
\text { sullied flesh would } \\
\text { melt, }\end{array}$ & & & & 2 & & & & & 2 & $20 \%$ \\
\hline 2 & $\begin{array}{l}\text { Thaw, and resolve } \\
\text { itself into a dew, }\end{array}$ & 1 & & & 1 & & & & & 2 & $20 \%$ \\
\hline 3 & $\begin{array}{l}\text { Or that the } \\
\text { Everlasting had not } \\
\text { fixed }\end{array}$ & & & & 1 & & & & & 1 & $10 \%$ \\
\hline 4 & $\begin{array}{l}\text { His canon 'gainst } \\
\text { self-slaughter! } \\
\text { God, God, }\end{array}$ & & & & & & 1 & 1 & & 2 & $20 \%$ \\
\hline 5 & $\begin{array}{l}\text { How weary, stale, } \\
\text { flat, and unprofitable }\end{array}$ & & & & & & & & 1 & 1 & $10 \%$ \\
\hline 6 & $\begin{array}{l}\text { Seem to me all the } \\
\text { uses of this world! }\end{array}$ & 1 & & & 1 & & & & & 2 & $20 \%$ \\
\hline & Total & 2 & - & - & 5 & - & 1 & 1 & 1 & 10 & $\begin{array}{l}33 \\
\%\end{array}$ \\
\hline & $\begin{array}{l}\text { Disagreement per } \\
\text { passage }\end{array}$ & $20 \%$ & - & - & $50 \%$ & - & $10 \%$ & $10 \%$ & $10 \%$ & $33 \%$ & 30 \\
\hline
\end{tabular}




\subsection{Statistical Analysis of the Passage:}

The statistics show that the amount of disagreement between foot and word boundaries in most of the feet is less than those of agreement. This reflects less conflict and tension between meter and syntax in this part of the play. The following chart shows this statistical analysis of the tension within the line:

Table 11 meter-syntax tension

\begin{tabular}{|c|c|c|c|c|c|c|c|}
\hline Foot & One & Two & Three & Four & Five & Total & $\%$ \\
\hline Agree & 4 & 3 & 2 & 2 & 5 & $\mathbf{1 6}$ & $\mathbf{5 3 \%}$ \\
\hline Disagree & 2 & 3 & 4 & 4 & 1 & $\mathbf{1 4}$ & $\mathbf{4 7 \%}$ \\
\hline
\end{tabular}

The following two charts show these cases of tension in the passage; the first one shows the relation between meter and syntax, and the second shows the poetic license used in the passage.

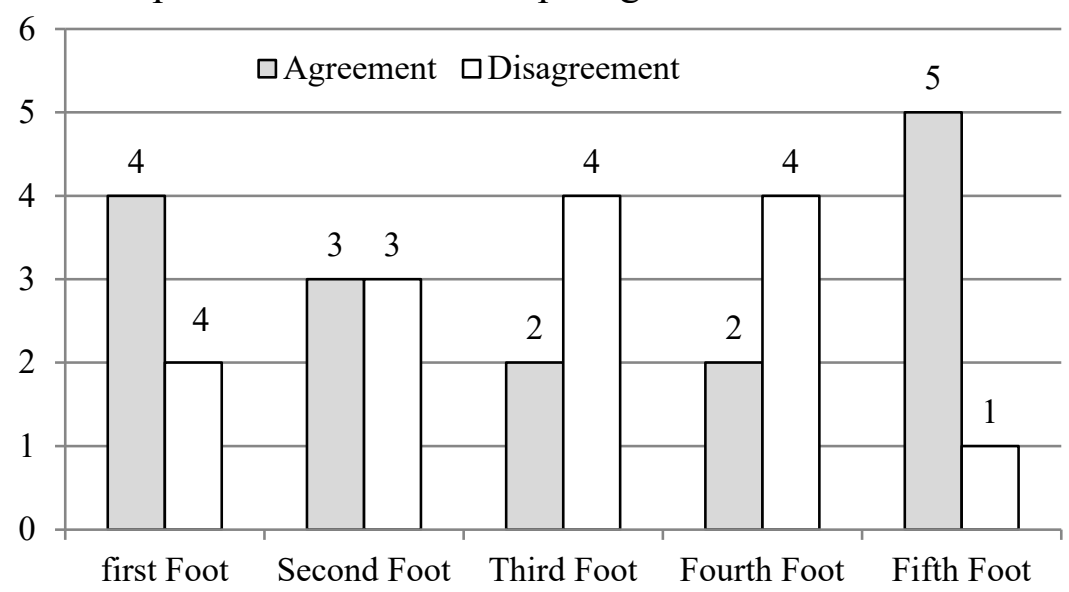

Fig. 5 meter-syntax

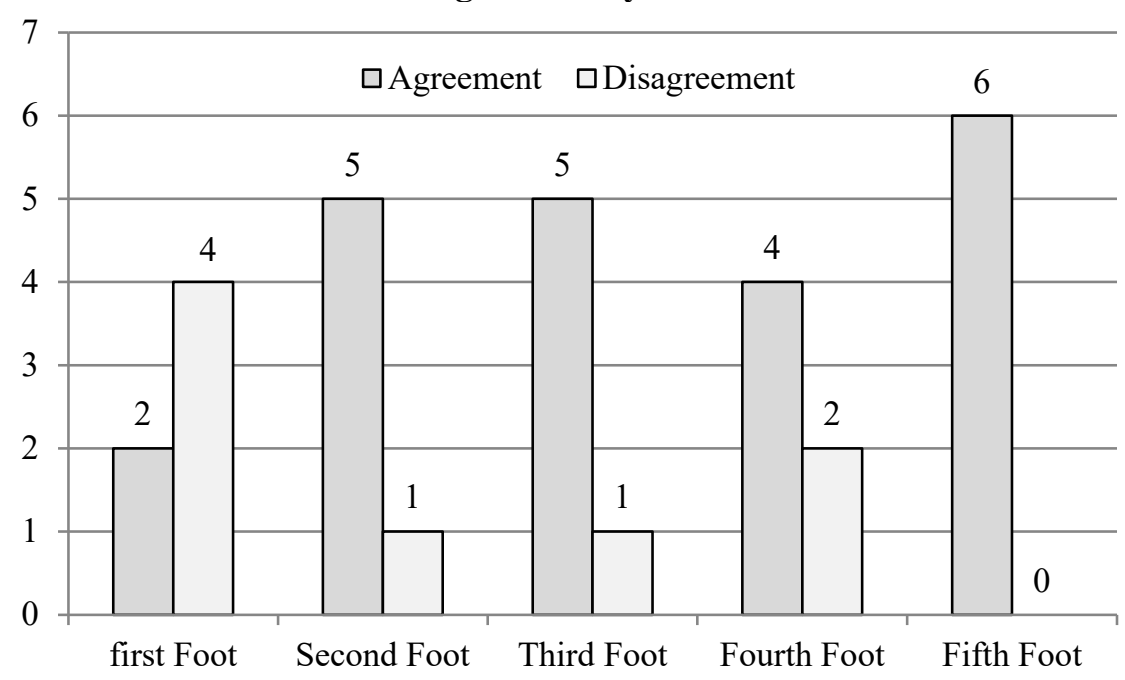

Fig. 6 poetic license 
This passage is taken from Hamlet's first soliloquy in act one, scene two. It comes directly after the conversation between him and his uncle about what happened recently in the state of Denmark such as the death of his father, king Hamlet, the marriage to his mother and the expected attacks from the new king of Norway. This is the first time for him to appear alone on the stage expressing his mourning and revealing his emotional state. Obviously, Hamlet is full of melancholy because of the death of his father, and he is also upset because of the hasty marriage of his mother to his uncle.

According to the above chart, it is clear that Shakespeare gives a wonderful depiction of Hamlet's mental state in this soliloquy. Hamlet wishes that he could disappear using the phrase "This sullied flesh could melt". Serageldin and Soyinka (1998) clarify that "the drama of Hamlet is incredibly more profound, and akin to the modern condition where the modern hero, or anti-hero, is torn between internal and external forces and is not just confronting the classical dramatic choices (loyalty versus honor, love versus duty)" (9). Hamlet mentions the fact that he cannot end his life by himself which reflects his strong belief in everlasting and mortality after death. He fears God's damnation. This speech is not fairly surprising to the audience or to the readers since the country of Denmark was a Christian one at the time of Shakespeare. Johnston (2001) states that "in Hamlet, it doesn't matter how people try to deal with life: they all fail. Life is too much for them" (8). So, Hamlet wishes that the everlasting and eternity can permit him self-slaughter or to be allowed to kill himself because he feels that he has nothing to do with this world. That is shown professionally in Shakespeare's language depicting him crying and shouting: "O God, O God".

Hamlet's speech shows him unable to endure the unpleasant scene which happened in the court when Claudius and Hamlet's mother asked him not to study abroad and to stay with them in Denmark. As a result, Hamlet thinks of suicide since he finds himself depressed and his life much more painful but he cannot do this because of his religion. Hamlet thinks a lot before talking. He cannot accept the fast marriage of his mother to his uncle. Furthermore, he is unable to realize what happened after the death of his father. This reflects a political aspect. Serageldin and Soyinka (1998) maintain that "the time of Shakespeare was an unusual time in the history of England" (21). Shakespeare describes his time and mentions facts about both political and religious aspects through the language of his drama. Serageldin and Soyinka (1998) think that:

The social and political climate also played a major role. It was a time of change. England was in the process of becoming a major European power. The feudal system 
was breaking down, but was only partially replaced by the system of bourgeois values that would consolidate their hold on English society only a century or so later (21).

\subsection{Syntactic Analysis of the Passage:}

As a result of what happened, Hamlet asks God if there is a way to commit suicide. He uses the word "self-slaughter" to mean that suicide is forbidden by God and that he wishes it is not seen a sin from God if he commits it. The soliloquy takes place after Claudius and Gertrude ask Hamlet to cast away his deep sadness. Hamlet is extremely upset because of their words and because of their early marriage. Johnston (2001) declares that:

Hamlet's soliloquies are marked by sudden changes of subject, self-urging to put something out of his mind accompanied by an inability to do so, attacks on himself for all his verbalizing, and a sense of despair that all this talk is getting him no closer to any sort of answer which will clarify the world sufficiently to enable him to act (6).

Hamlet wishes death especially after his mother has married to his uncle only one month after his father's death. Moreover, she marries her dead husband's brother. Hamlet feels that he does not want to live any more. Shakespeare portrays his characters in an innovative way. There a big amount of tension between meter and syntax in most of the third and fourth feet of each line. Bernáth (2013) states that "a play can be regarded as a mirror reflecting nature, and the theatre experience as a reflection of the world or reality, particularly ourselves, the nature of the audience who looks into the mirror of the play" (11).

The phrases: "Why she, even she", "within a month", "with such dexterity to incestuous sheets" and "Frailty, thy name is woman" in this first soliloquy by Hamlet in the play reveal his emotional state showing that he is extremely upset and in mourning for the hasty marriage. The first three lines of the soliloquy show the depiction of Hamlet's mental state. He wishes he could disappear. He does not want to be a part of this world anymore. Obviously, he mentions the fact that he cannot commit suicide or end his life by himself because he has a strong belief in mortality and everlasting which is a main theme in the play. Denmark, as Shakespeare mentions and portrays in the play, is a Christian country. So, Hamlet's thinking is not surprising when he remembers death, heaven and hell. He wishes his belief could allow him to kill himself. So, he is shouting " $\mathrm{O}$ God, God". This state of melancholy Hamlet lives evokes the audience to ask the question whether this sadness is because of his father's death or because of something else. He uses a considerable metaphor comparing 
the state of Denmark to an unseeded garden which has a lot of harmful trees that need to be cut or removed by which he thinks that there is always dust in Denmark.

\subsection{Lexical Statistics:}

The major word classes used in this passage are as follows:

Table 12 major word classes

\begin{tabular}{|r|c|c|c|c|}
\hline Part of speech & Nouns & Adjectives & Verbs & Adverbs \\
\hline Total number & 9 & 5 & 5 & 2 \\
\hline Percentage & $43 \%$ & $24 \%$ & $24 \%$ & $9 \%$ \\
\hline
\end{tabular}

Having a look at both the above table and the source passage, it is clear that nouns are used most. Verbs and adjectives are of the same amount and number. This clarifies that most lines have complete sentences and thoughts. Again, the big number of adjectives used in the passage reflects Hamlet's state of mind. He seems very angry and upset. The words "weary" and "unprofitable" reflects the fact that Hamlet has no need or use for the world and life anymore.

\section{Conclusion}

To sum up, it is noted that the statistical analysis of tension between meter and syntax is also aided by analyzing different types of poetic license used in the passage. These types include trochaic, feminine ending, ionic substitution, promotion, demotion and caesura. The most used one is promotion. Next, the feminine ending and ionic substitution come. These types of poetic license help in the tension between meter and syntax through enforcing the meaning.

Agreement and disagreement between meter and syntax in the discussed passages is the main focus of this study. The greater the disagreement between meter and syntax within the line, the stronger the tension between them. The two movements of agreement and disagreement affect the portrayal of the two main characters in the plays.

After analyzing these passages, it is obvious that Shakespeare uses long sentences. The statistics show that most disagreement between meter and syntax within the line occurs in the second foot of the line. The passages are full of rhetorical questions and exclamatory clauses. Hamlet is quite surprised at what he feels and sees around him. The use of very long sentences reinforces the feeling of loss and hesitation. He feels that he is lost. He thinks too much of the matter. He uses either compound or complex structures.

Enjambment is a very important device used to show the tension between meter and syntax since there are a lot of syntactic units that do not end within the metrical pattern of iambic pentameter. This enjambment breaks the metric norm and makes the meaning continue from one line to 
another. The punctuation used in the lines reflects this enjambment. Some lines have no end punctuation; others end with a comma or a colon. So, stopping at the end of these lines may not give the whole meaning.

As for poetic license, it is quite suitable to change the iambic norm into trochaic and ionic substitution since it gives a good description of the mood of Hamlet when he feels lost, searching for the truth through asking himself many long questions. Also, it is clear that the tension gets stronger when using the feminine ending that appears in many lines. This reflects the state of anger, hesitation and agitation. Hamlet seems impatient. He cannot control his feelings of anger. So, the structures become longer than the meter. But in some lines, the shorter structures are used. These short structures may be even shorter than the meter itself in one foot or more.

Hamlet seems to have a central political problem: to be the king and revenge or not. He is so impatient. He cannot wait since he feels very angry at being nothing while he should kill his uncle and become the king. These feelings and reactions to different situations are obvious to the audience through giving this insight of Hamlet's hesitating and his use of syntax and diction. Hamlet desires to set his own rule and right after achieving the ghost's wish of revenge. He uses many questions that express and reflect his mood of sorrow and anger. Through analyzing Hamlet's speech, it is clear that he uses metaphors to compare his country to a rotten place that will only lead to more infection. Of course, Hamlet has a duty to be achieved which is the killing of his uncle. In brief, it is clear that Shakespeare uses much more enjambment than end-stopped lines when he wants to keep the ideas linked from one line to the next, and also to show the inner emotions of his characters. This propels the reader forward with the story and its actions. While reading, he tries to make connections between the different syntactical units. Of course, the stops and pauses in the middle of sentences or clauses will emphasize particular words or thoughts. 
Appendix 1 Symbols and meanings

\begin{tabular}{|c|c|c|}
\hline 1 & $x-$ & lambic foot \\
\hline 2 & $-x$ & Trochaic foot \\
\hline 3 & $-\quad \times x$ & Dactylic foot \\
\hline 4 & $\times x-$ & Anapestic foot \\
\hline 5 & -- & Spondee \\
\hline 6 & $x \times$ & Pyrrhic \\
\hline 7 & $\uparrow$ & Promotion \\
\hline 8 & $\downarrow$ & Demotion \\
\hline 9 & $\|$ & Caesura \\
\hline
\end{tabular}

\section{References}

\section{Primary Sources:}

Shakespeare, William (1999). Hamlet. Ed. Jon Bosak.

England: Longman Group Ltd.

\section{Secondary Sources:}

Akram, Z. and Qasim, N. (2016). "Shakespeare's Use of ndirect Speech Acts in 'Hamlet'". International Journal of Humanities, Education and Social Sciences, pp.68-90.

Bernáth, A. (2013). "Hamlet, the Ghost and the Model Reader: The Problems of the Reception and a Concept of Shakespeare's Hamlet", szte. Bloom, H. (2009). "The Analysis of Character." Bloom's Major Literary Characters: Hamlet.

Bloom, H(2009). "Modern Critical Interpretations:William Shakespeare's Hamlet"-New Edition, Infobase Publishing .

Hadfield, Andrew (2014) "The Power and Rights of the Crown in Hamlet and King Lear." The Review of English Studies, New Series, Vol. 54, No. 217, pp. 566-586.

Oxford University Press. " .(2014) . - - -Shakespeare and Renaissance politics," A\&C Black.

Johnston, I. (2001). English 366: Studies in Shakespeare: Introductory Lecture on Shakespeare's Hamlet, Malaspina-University College, Nanaimo, BC. 
Keys, C. (2012). Shakespeare's Existentialism, University of London.

Malof, Joseph (1970). "A Manual of English Meters." Indian University Press.

Seely, A (2012). "Soliloquies and the Evolution of Character in Richard III and Hamlet." The University of Arizona.

Serageldin, I. \& Soyinka, W. (1998). "The Modernity of Shakespeare", Cairo University.

Sharma, S. L (2014). "Moral Lessons in Shakespearean Tragedies." Volume II, Issue V: 2321-7065.

Sjölin, M. (2017). "Stage Appropriations of Shakespeare's Major Tragedies, 1979-2010." 
المجلة العلمية لكلية الآداب مج 10، ع 1 (2021) 85 - 111 أمآ

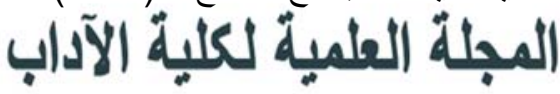

https://artdau.journals.ekb.eg/

المغايرة بين العروض والنحو في مسرحية "هاملت" لوليام شكسبير

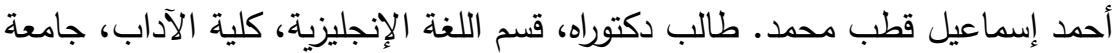

بورسعيد.

\section{المستخلص}

تهذف هذه الدراسة إلى بحث العلاقة والمغايرة ما بين العروض وتركيب الجملة في واحدة من أروع المسرحيات المأساوية للكاتب المسرحي العظيم ويليام شكسبير ألا و هي مسرحية هاملت، وشكسبير الحاذق المبدع وظف كلا من علمي العروض الشعري وتركيب الجملة اللغوي ليخدما المعنى الذي يريد توصيله إلى جمهورهو وقارئي أعماله. أحد أسباب خلود هذه المسرحية هو الاستخدام الفريد للغة و المفردات

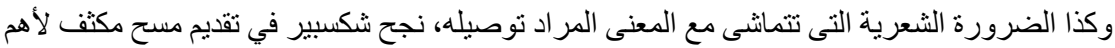
الأفكار التي راودت هاملت وتردده على وجه الدقة من خلال استخدام نظم شعري فريد يعكس انفعالات الثخصية، وكثف ما يدور في رأسة من خلال التركيب اللغوي الذي يستخدمه خاصة في مناجاته حينما يكون وحيدا على خشبة المسرح. ذكر النقاد أن شكسبير لم يكتب مطلقا بدون تخطيط دقيق مسبق، وهذا

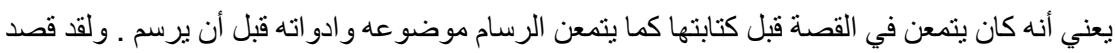
شكسبير في هاملت من خلال المغايرة بين العروض وتركيب الجملة تصوير وجهة نظر الإنسان بالعالم الخارجي، في أن كل حو ادثه وموضو عاته هي ، نسبيا"، مظلمة و غامضة و ولا رغبة له فيها بحد ذاتها . وأن الاهتمام بها يبدأ فقط حين تنعكس تلك الحو ادث و الموضو عات الخارجية بنفس الطريقة التي ينظر بها الرجل ذو الخيال المفعم بالنشاط، الذي يغمض عينه ليرى أثنياء سابقة تركت انطباعاتها فيه، فقد انشطر على نفسه فكان شطره الثاني ثورة غاضبة وهذيانا" و انفعالا" ضد نفسه على إهماله تنفيذ و اجبه المهيب الذي أوكل إليه. إن هاملت في الحقيقة هو مجرد اسم، وكل أقو اله وخطبه وحتى صياغاته الساذجة هي من عقل الثاعر شكسبير الذي عكس ذللك بعبقريته في توظيف النظم واللغة لتوضيح مشكلة هاملت الرئيسة ألا و هي عدم قدرته على اتخاذ قرار.

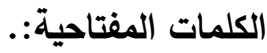

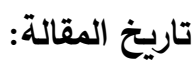
تاريخ اسـتلام المقالـة: 20 يناير 2021 تاريخ استلام النسخة النهائية: 9 فبراير 2021 تاريخ قبــول المقالـــة: 3 مارس 2021 